\title{
Georgenia halophila sp. nov., a halophilic actinobacterium isolated from a salt lake
}

Correspondence

Wen-Jun Li

wjli@ynu.edu.cn or

liact@hotmail.com

\author{
Shu-Kun Tang, ${ }^{1} \dagger$ Yun Wang, ${ }^{2} \dagger$ Jae-Chan Lee, ${ }^{3}$ Kai Lou, ${ }^{2}$ Dong-Jin Park, ${ }^{3}$ \\ Chang-Jin $\mathrm{Kim}^{3}$ and Wen-Jun $\mathrm{Li}^{1}$
}

\author{
${ }^{1}$ The Key Laboratory for Microbial Resources of the Ministry of Education and Laboratory for \\ Conservation and Utilization of Bio-Resources, Yunnan Institute of Microbiology, Yunnan \\ University, Kunming 650091, PR China \\ ${ }^{2}$ Xinjiang Institute of Microbiology, Xinjiang Academy of Agricultural Science, Urumqi, Xinjiang \\ 830091, PR China \\ ${ }^{3}$ Functional Metabolite Research Center, KRIBB, 52 Eoeun-dong, Yuseong gu, Daejeon 305-806, \\ Republic of Korea
}

\begin{abstract}
A Gram-stain-positive actinobacterium, designated strain YIM $93316^{\top}$, was isolated from a salt lake in Xinjiang Province, north-west China, and was subjected to a polyphasic taxonomic study. The isolate grew at $10-45{ }^{\circ} \mathrm{C}$, at $\mathrm{pH} 6-9$ and in the presence of $1-15 \%(\mathrm{w} / \mathrm{v}) \mathrm{NaCl}$, but no growth was observed in the absence of $\mathrm{NaCl}$. The cell-wall diamino acid contained alanine, glutamine and lysine with peptidoglycan type $\mathrm{A} 4 \alpha$. Polar lipids contained diphosphatidylglycerol, phosphatidylglycerol, phosphatidylinositol, phosphatidylinositol mannosides, an unknown glycolipid and an unknown phospholipid. The predominant menaquinone was $\mathrm{MK}-8\left(\mathrm{H}_{4}\right)$. The major fatty acids were anteiso- $\mathrm{C}_{15: 0}$ and anteiso- $\mathrm{C}_{15: 1}$. The DNA G+C content of strain YIM $93316^{\top}$ was 70.1 mol\%. Chemotaxonomic properties supported the affiliation of strain YIM $93316^{\top}$ to the genus Georgenia, and this was supported by phylogenetic analysis based on $16 \mathrm{~S}$ rRNA gene sequences. Levels of $16 \mathrm{~S}$ rRNA gene sequence similarity between strain YIM $93316^{\top}$ and Georgenia thermotolerans TT02-04 ${ }^{\top}$, Georgenia ruanii YIM $004^{\top}$ and Georgenia muralis $1 \mathrm{~A}-$ $\mathrm{C}^{\top}$ were $96.6,96.5$ and $96.3 \%$, respectively. Data from fatty acid, physiological and biochemical tests allowed the clear phenotypic differentiation of strain YIM $93316^{\top}$ from recognized members of the genus Georgenia. On the basis of evidence from the present polyphasic study, strain YIM $93316^{\top}$ is considered to represent a novel species of the genus Georgenia, for which the name Georgenia halophila sp. nov. is proposed. The type strain is YIM $93316^{\top}\left(=\mathrm{DSM} 21365^{\top}\right.$ $=$ CCTCC AB 208144 ${ }^{\top}$ ).
\end{abstract}

The genus Georgenia was proposed by Altenburger et al. (2002) with the description of Georgenia muralis as the type species, and the description was later emended by Li et al. (2007). At the time of writing, the genus comprises three recognized species, namely G. muralis (Altenburger et al., 2002), Georgenia ruanii (Li et al., 2007) and Georgenia thermotolerans (Hamada et al., 2009). Members of the genus Georgenia are Gram-positive, aerobic or facultatively anaerobic, non-endospore-forming, oxidase- and catalasepositive, motile or non-motile actinobacteria, with pepti-

†These authors contributed equally to this work.

The GenBank/EMBL/DDBJ accession number for the 16S rRNA gene sequence of strain YIM $93316^{\top}$ is FJ717681.

Chromatograms of O-phthalaldehyde- and 1-phenyl-3-methyl-5-pyrazolone-derivatization samples of cell walls of strain YIM $93316^{\top}$ and a figure showing the polar lipid composition of strain YIM 93316 ${ }^{\top}$ are available as supplementary material with the online version of this paper. doglycan type $\mathrm{A} 4 \alpha$ (lysine as the diagnostic diamino acid), MK-8 $\left(\mathrm{H}_{4}\right)$ as the predominant menaquinone, anteiso$\mathrm{C}_{15: 0}$ as the major fatty acid and DNA G+C content of 70-73 mol\%.

Strain YIM $93316^{\mathrm{T}}$ was isolated from a soil sample collected from Qijiaojing Lake in Xinjiang Province, north-west China (GPS coordinates for the sampling site are $43^{\circ} 23^{\prime} 01^{\prime \prime} \mathrm{N} 91^{\circ} 36^{\prime} 11^{\prime \prime} \mathrm{E}$ ), after 3 weeks of incubation at $37{ }^{\circ} \mathrm{C}$ on glucose-tryptone-yeast (GTY) medium [per litre distilled water: $1 \mathrm{~g}$ glucose, $0.5 \mathrm{~g}$ tryptone, $2 \mathrm{~g}$ yeast extract, $1 \mathrm{~g} \mathrm{CaCl}_{2}, 100 \mathrm{~g} \mathrm{NaCl}$ and $15 \mathrm{~g}$ agar; final $\mathrm{pH}$ 7.5]. Strain YIM $93316^{\mathrm{T}}$ was maintained on GTY agar slants containing $10 \% \mathrm{NaCl}(\mathrm{w} / \mathrm{v})$ at $4{ }^{\circ} \mathrm{C}$ and as glycerol suspensions $(20 \%, \mathrm{v} / \mathrm{v})$ at $-20{ }^{\circ} \mathrm{C}$. Biomass for chemical and molecular studies was obtained by cultivation in shaken flasks (about 150 r.p.m.) with GTY liquid medium [10\% (w/v) $\mathrm{NaCl}, \mathrm{pH} 7.5]$ at $37{ }^{\circ} \mathrm{C}$ for 1 week. 
Cell morphology was determined after 6, 12, 24, 48 and $72 \mathrm{~h}$ incubation on GTY agar medium supplemented with $10 \%(\mathrm{w} / \mathrm{v}) \mathrm{NaCl}$ at $37{ }^{\circ} \mathrm{C}$. Gram staining was carried out by the standard Gram reaction and was confirmed by using the $\mathrm{KOH}$ lysis test method (Cerny, 1978). Cell motility was confirmed based on the presence of turbidity throughout the tube including semisolid medium (Leifson, 1960). Morphological characteristics of the novel strain were observed by light microscopy (model BH 2; Olympus) and by transmission electron microscopy (model H-800; Hitachi). Growth was tested at $4-55{ }^{\circ} \mathrm{C}$ on GTY medium containing $10 \%(\mathrm{w} / \mathrm{v}) \mathrm{NaCl}$, at intervals of $5{ }^{\circ} \mathrm{C}$. For $\mathrm{NaCl}$ tolerance experiments, GTY medium was used as the basal medium with salt concentrations from 0 to $20 \%$ (w/v), at intervals of $1 \%$. The $\mathrm{pH}$ range for growth was investigated between $\mathrm{pH} 4.0$ and 10.0 at intervals of $1 \mathrm{pH}$ unit. The buffer system was as follows: $\mathrm{pH} 4.0-5.0,0.1 \mathrm{M}$ citric acid/ $0.1 \mathrm{M}$ sodium citrate; $\mathrm{pH} 6.0-8.0,0.1 \mathrm{M} \mathrm{KH}_{2} \mathrm{PO}_{4} / 0.1 \mathrm{M}$ $\mathrm{NaOH} ;$ pH 9.0-10.0, $0.1 \mathrm{M} \quad \mathrm{NaHCO}_{3} / 0.1 \mathrm{M} \quad \mathrm{Na}_{2} \mathrm{CO}_{3}$. Catalase activity was determined by production of bubbles after the addition of a drop of $3 \% \mathrm{H}_{2} \mathrm{O}_{2}$. Oxidase activity was observed by oxidation of tetramethyl- $p$-phenylenediamine. Hydrolysis of aesculin, casein, chitin, cellulose, dextrin, gelatin, starch and Tweens 20,40, 60 and 80 was determined as described by Cowan \& Steel (1965). Physiological and biochemical tests were performed by using the API ZYM, API Coryne, API $20 \mathrm{E}$ and API 50CHB systems (bioMérieux) according to the manufacturer's instructions. Inocula were prepared by using pre-warmed sterile saline medium $(10 \% \mathrm{NaCl})$, within the density range specified by the manufacturer. API 50CHB and API ZYM tests were performed in duplicate. Anaerobic growth experiments were performed in GTY medium supplemented with $0.15 \mathrm{mM}$ nitrate and $0.035 \mathrm{mM}$ nitrite by using a GasPak Anaerobic System (BBL) according to the manufacturer's instructions. The detailed physiological and biochemical properties of strain YIM $93316^{\mathrm{T}}$ are given in Table 1 and in the species description.

The peptidoglycan of cells of strain YIM $93316^{\mathrm{T}}$ was isolated after disruption of the cells by shaking with glass beads and subsequent trypsin digestion, according to the method of Schleifer (1985). The cell wall was hydrolysed for amino acid and sugar analyses as described by Schleifer \& Kandler (1972). Amino acids in cell-wall hydrolysates were analysed by precolumn derivatization with $O$ phthalaldehyde by HPLC (Tang et al., 2009a, b). G. ruanii YIM $004^{\mathrm{T}}$ was used as the reference strain for analysis of cell-wall amino acids. Whole-cell sugars were detected by precolumn derivatization with 1-phenyl-3-methyl-5-pyrazolone by HPLC (Tang et al., 2009b). Polar lipids were extracted, examined by two-dimensional TLC and identified by using published procedures (Minnikin et al., 1984). Menaquinones were isolated according to the method of Minnikin et al. (1984) and separated by HPLC (Kroppenstedt, 1982). For analysis of fatty acids, strain YIM $93316^{\mathrm{T}}$ was cultured on trypticase soy agar (TSA; Difco) containing $10 \% \mathrm{NaCl}$ at $37{ }^{\circ} \mathrm{C}$ for $72 \mathrm{~h}$.
Preparation and analysis of fatty acid methyl esters were performed as described by Sasser (1990) by using the Microbial Identification System (MIDI).

The cell-wall diamino acid of strain YIM $93316^{\mathrm{T}}$ contained glutamine, alanine and lysine (Supplementary Fig. S1, available in IJSEM Online), which is similar to results for G. ruanii YIM $004^{\mathrm{T}}$ and is characteristic of the genus Georgenia (peptidoglycan type A4 $\alpha$, murein type A11.54; http://www.dsmz.de/microorganisms/main.php?content_ id=35). Major whole-cell-wall sugars were rhamnose $(38.2 \%)$, glucosamine $(31.7 \%)$ and galactose $(10.3 \%)$; minor amounts of mannose $(7.1 \%)$, glucose $(6.3 \%)$ and xylose $(6.4 \%)$ were detected (Supplementary Fig. S2). The polar lipids contained diphosphatidylglycerol, phosphatidylglycerol, phosphatidylinositol, phosphatidylinositol mannosides, an unknown glycolipid and an unknown phospholipid (Supplementary Fig. S3). The predominant menaquinone was MK-8 $\left(\mathrm{H}_{4}\right)$. Strain YIM $93316^{\mathrm{T}}$ had a cellular fatty acid profile that contained large amounts of branched fatty acids; the major components $(>10 \%$ of the total) were anteiso- $\mathrm{C}_{15: 0}(69.8 \%)$ and anteiso- $\mathrm{C}_{15: 1}$ $(14.2 \%)$. Minor fatty acids detected were iso- $\mathrm{C}_{14: 0}(1.6 \%)$, $\mathrm{C}_{14: 0}(1.9 \%)$, iso- $\mathrm{C}_{15: 0}(6.1 \%), \mathrm{C}_{16: 0}(1.6 \%)$, anteiso$\mathrm{C}_{17: 0}(3.4 \%)$ and $\mathrm{C}_{18: 0}(1.4 \%)$.

Extraction of genomic DNA and PCR amplification of the 16S rRNA gene were performed as described by Li et al. (2007). Multiple alignments with sequences of the type strains of Georgenia species and calculations of levels of $16 \mathrm{~S}$ rRNA gene sequence similarity were carried out by using the EzTaxon server 2.0 (Chun et al., 2007). Phylogenetic analyses were performed by using the neighbour-joining (Saitou \& Nei, 1987), maximum-likelihood (Felsenstein, 1981) and maximum-parsimony (Fitch, 1971) methods. A phylogenetic tree was constructed with the neighbourjoining method of Saitou \& Nei (1987) from $K_{\text {nuc }}$ values (Kimura, 1980) by using MEGA version 4.0 (Tamura et al., 2007). The topology of the phylogenetic tree was evaluated by the bootstrap resampling method of Felsenstein (1985) with 1000 replicates. Genomic DNA of strain YIM $93316^{\mathrm{T}}$ for determination of $\mathrm{G}+\mathrm{C}$ content was prepared according to the method of Marmur (1961). The $\mathrm{G}+\mathrm{C}$ content of the DNA was determined by reversed-phase HPLC of nucleosides according to Mesbah et al. (1989).

Searches with the BLAST program showed that strain YIM $93316^{\mathrm{T}}$ had highest $16 \mathrm{~S}$ rRNA gene sequence similarity to members of the genus Georgenia. A phylogenetic tree was constructed with sequences of representative strains of the genus Georgenia, and Brevibacterium linens DSM 20425 was used as the outgroup. In the phylogenetic tree based on the neighbour-joining algorithm, strain YIM $93316^{\mathrm{T}}$ formed a monophyletic clade within the evolutionary radiation occupied by the genus Georgenia (Fig. 1). Similar topologies were found in the maximum-likelihood and maximum-parsimony trees. Levels of 16S rRNA gene sequence similarity between strain YIM $93316^{\mathrm{T}}$ and $G$. thermotolerans TT02-04 ${ }^{\mathrm{T}}$, G. ruanii YIM $004^{\mathrm{T}}$ and $G$. 
Table 1. Differential characteristics between strain YIM $93316^{\top}$ and members of the genus Georgenia

Strains: 1, YIM 93316 ${ }^{\mathrm{T}}$; 2, G. thermotolerans TT02-04 ${ }^{\mathrm{T}}$ (data from Hamada et al., 2009); 3, G. ruanii YIM 004 ${ }^{\mathrm{T}}$ (Li et al., 2007; Hamada et al., 2009); 4, G. muralis 1A-C $\mathrm{C}^{\mathrm{T}}$ (Altenburger et al., 2002; Hamada et al., 2009). +, Positive; -, negative; w, weakly positive, ND, no data available.

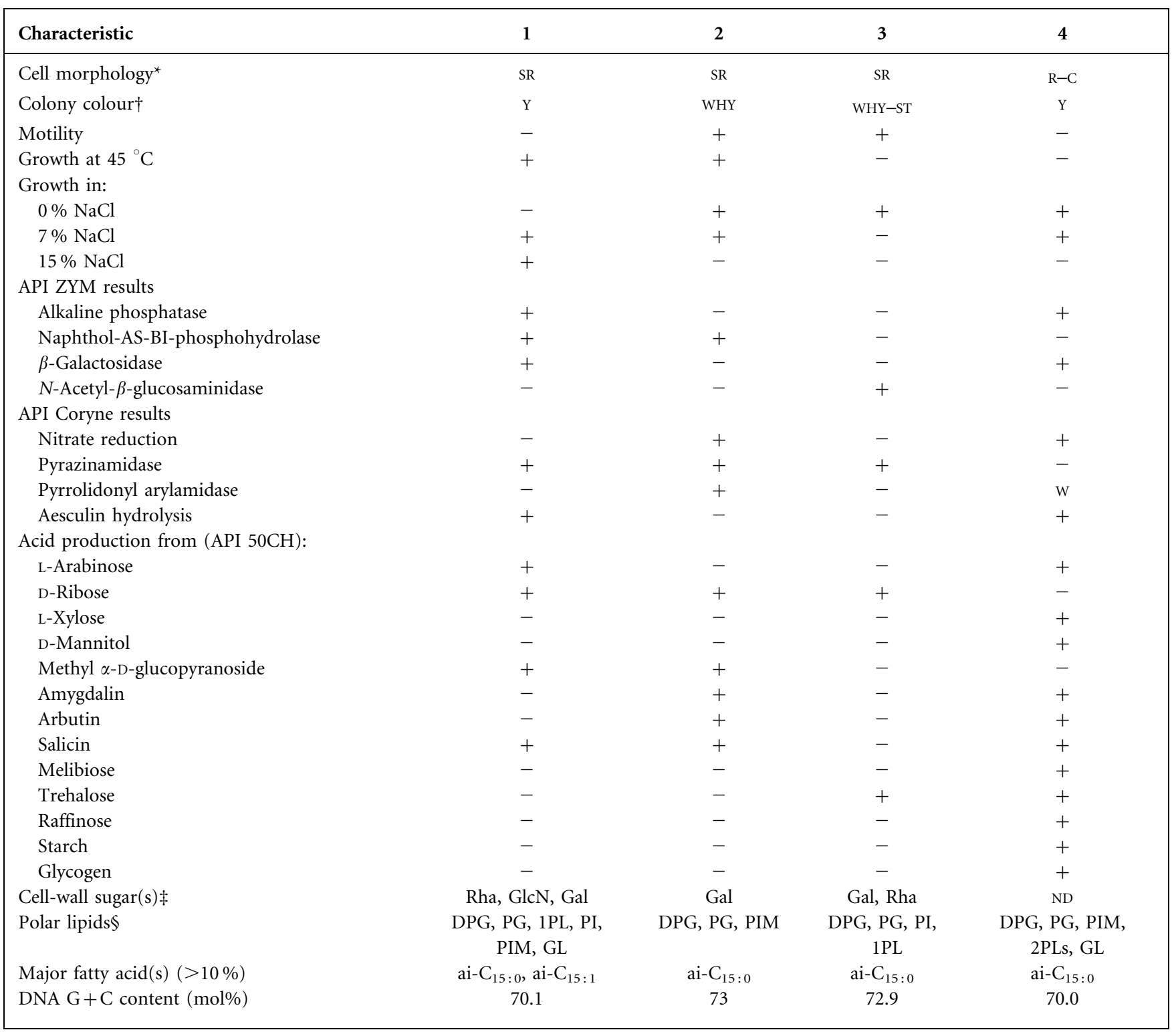

${ }^{*} \mathrm{R}-\mathrm{C}$, Rod-coccus cycle; SR, short rods.

$\dagger$ ST, Straw-coloured; WHY, whitish yellow; y, yellow.

‡Gal, Galactose; GlcN, glucosamine; Rha, rhamnose.

§DPG, Diphosphatidylglycerol; PG, phosphatidylglycerol; PI, phosphatidylinositol; PIM, phosphatidylinositol mannosides; PL, unknown phospholipid; GL, unknown glycolipid.

muralis $1 \mathrm{~A}-\mathrm{C}^{\mathrm{T}}$ were $96.6,96.5$ and $96.3 \%$, respectively. The $\mathrm{G}+\mathrm{C}$ content of the DNA of strain YIM $93316^{\mathrm{T}}$ was $70.1 \mathrm{~mol} \%$.

The chemotaxonomic properties of strain YIM $93316^{\mathrm{T}}$ [peptidoglycan type $\mathrm{A} 4 \alpha$; anteiso- $\mathrm{C}_{15: 0}$ as the major fatty acid; diphosphatidylglycerol and phosphatidylglycerol as major phospholipids; MK- $8\left(\mathrm{H}_{4}\right)$ as the predominant menaquinone] indicated an affiliation to the genus Georgenia (Altenburger et al., 2002; Li et al., 2007; Hamada et al., 2009). 16S rRNA gene sequence analysis also indicated that strain YIM $93316^{\mathrm{T}}$ had closest phylogenetic affiliation to the genus Georgenia, which was confirmed by a high bootstrap resampling value. Therefore, both chemotaxonomic and phylogenetic results clearly indicated that strain YIM $93316^{\mathrm{T}}$ belongs to the genus 


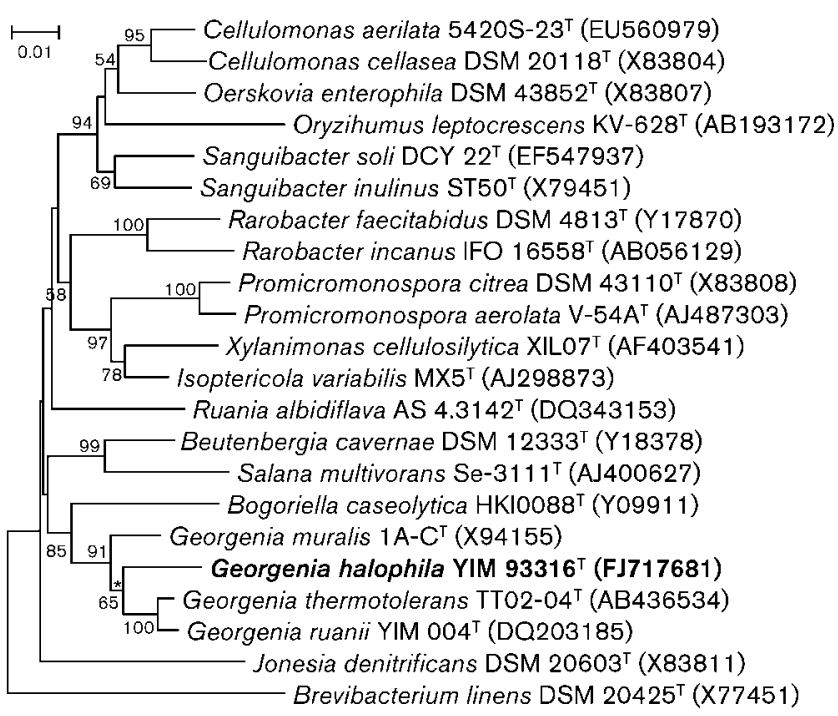

Fig. 1. Neighbour-joining phylogenetic dendrogram obtained by distance-matrix analysis of 16S rRNA gene sequences, showing the position of strain YIM $93316^{\top}$ and its phylogenetic neighbours. Asterisks indicate branches of the tree that were also found by using the maximum-likelihood and maximum-parsimony treemaking algorithms. Numbers at nodes are bootstrap values (percentages based on 1000 resamplings, only values $>50 \%$ are given). The sequence of Brevibacterium linens DSM $20425^{\top}$ was used as the outgroup. Bar, $1 \%$ sequence divergence.

Georgenia. However, YIM $93316^{\mathrm{T}}$ could be differentiated from members of the genus Georgenia based on several morphological, physiological and chemotaxonomic properties (Table 1). In particular, strain YIM $93316^{\mathrm{T}}$ was a halophilic actinobacterium; growth was observed at up to $15 \% \mathrm{NaCl}$, but no growth occurred in the absence of $\mathrm{NaCl}$. By contrast, recognized members of the genus Georgenia are non-halophilic actinobacteria that are able to grow without $\mathrm{NaCl}$ and do not grow in the presence of $15 \%$ $\mathrm{NaCl}$. Furthermore, strain YIM $93316^{\mathrm{T}}$ exhibited differences from recognized members of the genus Georgenia in its fatty acid composition. For instance, strain YIM $93316^{\mathrm{T}}$ contained anteiso- $\mathrm{C}_{15: 0}$ and anteiso- $\mathrm{C}_{15: 1}$ as major fatty acids $(>10 \%)$, whereas recognized Georgenia species do not have anteiso- $\mathrm{C}_{15: 1}$ as a major component.

Therefore, on the basis of its phenotypic and genotypic distinctiveness, strain YIM $93316^{\mathrm{T}}$ is considered to represent a novel species of the genus Georgenia, for which we propose the name Georgenia halophila sp. nov.

\section{Description of Georgenia halophila sp. nov.}

Georgenia halophila (ha.lo.phi'la. Gr. n. hals, halos salt; Gr. adj. philos loving; N.L. fem. adj. halophila salt-loving, referring to the ability of the type strain to grow at high $\mathrm{NaCl}$ concentrations).

Cells are Gram-stain-positive, facultatively anaerobic, nonmotile, non-endospore-forming, short rods $(0.2-0.5 \mu \mathrm{m}$ in diameter). Colonies are yellow, circular, opaque, slightly convex, smooth and approximately $1.0 \mathrm{~mm}$ in diameter after $24 \mathrm{~h}$ at $37{ }^{\circ} \mathrm{C}$. No water-soluble exopigment is formed. Grows at $10-45^{\circ} \mathrm{C}$, at $\mathrm{pH}$ 6.0-9.0 and in the presence of $1-15 \%(\mathrm{w} / \mathrm{v}) \mathrm{NaCl}$; no growth is observed at 4 or $50{ }^{\circ} \mathrm{C}$, above $\mathrm{pH} 10$ or in the presence of $16 \% \mathrm{NaCl}$; optimal growth occurs in the presence of $5-10 \% \mathrm{NaCl}$, at pH 7.0-8.0 and at $37{ }^{\circ} \mathrm{C}$. Oxidase- and catalase-positive. Voges-Proskauer and methyl red tests are negative. Positive for hydrolysis of starch, aesculin and Tween 80, but negative for hydrolysis of gelatin, chitin, cellulose, dextrin, urea, casein and Tweens 20, 40 and 60. Indole and $\mathrm{H}_{2} \mathrm{~S}$ are not produced. Nitrate reduction is positive. In the API 50CHB system, acid is produced from glycerol, D- and L-arabinose, D-ribose, D-xylose, D-galactose, D-glucose, Dmannose, L-rhamnose, methyl $\alpha$-D-mannopyranoside, aesculin, salicin, sucrose, D-lyxose, L-fucose and potassium 5ketogluconate, but not erythritol, L-xylose, D-adonitol, methyl $\beta$-D-xylopyranoside, D-fructose, dulcitol, inositol, D-mannitol, D-sorbitol, methyl $\alpha$-D-glucopyranoside, $N$ acetylglucosamine, amygdalin, arbutin, cellobiose, maltose, lactose, melibiose, trehalose, inulin, melezitose, raffinose, starch, glycogen, xylitol, gentiobiose, turanose, D-tagatose, D-fucose, DL-arabitol, potassium gluconate or potassium 2ketogluconate. In the API Coryne system, positive for alkaline phosphatase, $N$-acetyl- $\beta$-glucosaminidase, pyrazinamidase and aesculin hydrolysis, but negative for nitrate reduction, $\alpha$-glucosidase, $\beta$-glucosidase, pyrrolidonyl arylamidase, $\beta$-glucuronidase, $\beta$-galactosidase, urease and gelatin hydrolysis. In the API ZYM system, positive for alkaline phosphatase, esterase (C4), esterase lipase (C8), leucine arylamidase, naphthol-AS-BI-phosphohydrolase, $\alpha$ galactosidase, $\beta$-galactosidase, $\beta$-glucosidase and $\alpha$-mannosidase, but negative for valine arylamidase, cystine arylamidase, trypsin, $\alpha$-glucosidase, lipase (C14), $\alpha$-chymotrypsin, acid phosphatase, $\beta$-glucuronidase, $N$-acetyl- $\beta$ glucosaminidase and $\alpha$-fucosidase. The peptidoglycan type is $\mathrm{A} 4 \alpha$. The major whole-cell-wall sugars are rhamnose, glucosamine and galactose. The polar lipids are diphosphatidylglycerol, phosphatidylglycerol, phosphatidylinositol, phosphatidylinositol mannosides, an unknown glycolipid and an unknown phospholipid. The predominant menaquinone is $\mathrm{MK}-8\left(\mathrm{H}_{4}\right)$. The major cellular fatty acids are anteiso- $\mathrm{C}_{15: 0}$ and anteiso- $\mathrm{C}_{15: 1}$; minor straightchain fatty acids are detected. The $\mathrm{G}+\mathrm{C}$ content of the DNA of the type strain is $70.1 \mathrm{~mol} \%$.

The type strain, YIM $93316^{\mathrm{T}}\left(=\mathrm{DSM} 21365^{\mathrm{T}}=\right.$ CCTCC AB $208144^{\mathrm{T}}$ ), was isolated from a salt lake sample collected from Qijiaojing Lake in Xinjiang Province, north-west China.

\section{Acknowledgements}

This research was supported by the National Basic Research Program of China (no. 2010CB833800), the National Natural Science Foundation of China (30860002, 30870005), the 973 Pre-research Program of China (2008CB417214), Youth Technological Innovation Foundation of Xinjiang Academy of Agricultural Science (no. 
2007Q07), the Open Project Program of the Extremophiles Lab of Xinjiang (no. XJYS0203-2005-01) and Korea Foundation for International Cooperation of Science \& Technology through a grant provided by the Korean Ministry of Education, Science and Technology in Global Partnership Program.

\section{References}

Altenburger, P., Kämpfer, P., Schumann, P., Vybiral, D., Lubitz, W. \& Busse, H.-J. (2002). Georgenia muralis gen. nov., sp. nov., a novel actinobacterium isolated from a medieval wall painting. Int $J$ Syst Evol Microbiol 52, 875-881.

Cerny, G. (1978). Studies on aminopeptidase for the distinction of Gram-negative from Gram-positive bacteria. Eur J Appl Microbiol Biotechnol 5, 113-122.

Chun, J., Lee, J.-H., Jung, Y., Kim, M., Kim, S., Kim, B. K. \& Lim, Y. W. (2007). EzTaxon: a web-based tool for the identification of prokaryotes based on $16 \mathrm{~S}$ ribosomal RNA gene sequences. Int J Syst Evol Microbiol 57, 2259-2261.

Cowan, S. T. \& Steel, K. J. (1965). Manual for the Identification of Medical Bacteria. London: Cambridge University Press.

Felsenstein, J. (1981). Evolutionary trees from DNA sequences: a maximum likelihood approach. J Mol Evol 17, 368-376.

Felsenstein, J. (1985). Confidence limits on phylogenies: an approach using the bootstrap. Evolution 39, 783-791.

Fitch, W. M. (1971). Toward defining the course of evolution: minimum change for a specific tree topology. Syst Zool 20, 406-416.

Hamada, M., Tamura, T., Ishida, Y. \& Suzuki, K. (2009). Georgenia thermotolerans sp. nov., an actinobacterium isolated from forest soil. Int J Syst Evol Microbiol 59, 1875-1879.

Kimura, M. (1980). A simple method for estimating evolutionary rates of base substitutions through comparative studies of nucleotide sequences. J Mol Evol 16, 111-120.

Kroppenstedt, R. M. (1982). Separation of bacterial menaquinones by HPLC using reverse phase (RP18) and a silver loaded ion exchanger as stationary phases. J Liq Chromatogr 5, 2359-2367.
Leifson, E. (1960). Atlas of Bacterial Flagellation. London: Academic Press.

Li, W.-J., Xu, P., Schumann, P., Zhang, Y.-O., Pukall, R., Xu, L.-H., Stackebrandt, E. \& Jiang, C.-L. (2007). Georgenia ruanii sp. nov., a novel actinobacterium isolated from forest soil in Yunnan (China), and emended description of the genus Georgenia. Int J Syst Evol Microbiol 57, 1424-1428.

Marmur, J. (1961). A procedure for the isolation of deoxyribonucleic acid from microorganisms. J Mol Biol 3, 208-218.

Mesbah, M., Premachandran, U. \& Whitman, W. B. (1989). Precise measurement of the $\mathrm{G}+\mathrm{C}$ content of deoxyribonucleic acid by highperformance liquid chromatography. Int J Syst Bacteriol 39, 159167.

Minnikin, D. E., O'Donnell, A. G., Goodfellow, M., Alderson, G., Athalye, M., Schaal, A. \& Parlett, J. H. (1984). An integrated procedure for the extraction of bacterial isoprenoid quinones and polar lipids. J Microbiol Methods 2, 233-241.

Saitou, N. \& Nei, M. (1987). The neighbor-joining method: a new method for reconstructing phylogenetic trees. Mol Biol Evol 4, 406425.

Sasser, M. (1990). Identification of bacteria by gas chromatography of cellular fatty acids. USFCC Newsl 20, 16.

Schleifer, K. H. (1985). Analysis of the chemical composition and primary structure of murein. Methods Microbiol 18, 123-156.

Schleifer, K. H. \& Kandler, O. (1972). Peptidoglycan types of bacterial cell walls and their taxonomic implications. Bacteriol Rev 36, 407-477.

Tamura, K., Dudley, J., Nei, M. \& Kumar, S. (2007). MEGA4: molecular evolutionary genetics analysis (MEGA) software version 4.0. Mol Biol Evol 24, 1596-1599.

Tang, S.-K., Wang, Y., Lou, K., Mao, P.-H., Xu, L.-H., Jiang, C.-L., Kim, C.-J. \& Li, W.-J. (2009a). Kocuria halotolerans sp. nov., an actinobacterium isolated from a saline soil in China. Int J Syst Evol Microbiol 59, 1316-1320.

Tang, S.-K., Wang, Y., Chen, Y., Lou, K., Cao, L.-L., Xu, L.-H. \& Li, W.-J. (2009b). Zhihengliuella alba sp. nov., and emended description of the genus Zhihengliuella. Int J Syst Evol Microbiol 59, 2025-2032. 